\title{
Zooplankton diversity of Loktak Lake, Manipur, India
}

\author{
B.K. Sharma ${ }^{1} \&$ Sumita Sharma ${ }^{2}$
}

\begin{abstract}
1,2 Freshwater Biology Laboratory, Department of Zoology, North-Eastern Hill University, Permanent Campus, Umshing, Shillong, Meghalaya 793022, India

Email: ${ }^{1}$ profbksharma@gmail.com (corresponding author), ${ }^{2}$ sumitasharma.nehu@gmail.com
\end{abstract}

\author{
Date of publication (online): 26 May 2011 \\ Date of publication (print): 26 May 2011 \\ ISSN $0974-7907$ (online) | 0974-7893 (print) \\ Editor: M.M. Saxena \\ Manuscript details: \\ Ms \# 02457 \\ Received 11 May 2010 \\ Final received 13 January 2011 \\ Finally accepted 27 April 2011
}

Citation: Sharma, B.K. \& S. Sharma (2011) Zooplankton diversity of Loktak Lake, Manipur, India. Journal of Threatened Taxa 3(5): 17451755 .

Copyright: (C) B.K. Sharma \& Sumita Sharma 2011. Creative Commons Attribution 3.0 Unported License. JoTT allows unrestricted use of this article in any medium for non-profit purposes, reproduction and distribution by providing adequate credit to the authors and the source of publication.

Author Details: Drs. BK Sharma and Sumita Sharma specialize in aquatic biodiversity and limnology and have made significant contributions to faunal diversity, biogeography and ecology of freshwater zooplankton of India. The corresponding author is a Professor in Department of Zoology and Dean, School of Life Sciences, NEHU, Shillong.

Author Contribution: The present study is the result of work undertaken by the authors at the Freshwater Biology Laboratory, Department of Zoology, North-Eastern Hill University, Shillong.

Acknowledgements: This study is undertaken partly under the "Potential for Excellence Program (Focused Area: Biosciences)" of NorthEastern Hill University, Shillong. The senior author is thankful to the G.B. Pant Institute of Himalayan Environmental Development, Almora for a research grant during which this study was initiated. Thanks are due to the Head, Department of Zoology, North-Eastern Hill University, Shillong for necessary laboratory facilities.

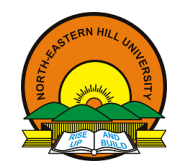

Abstract: Zooplankton communities of Loktak Lake showed rich and speciose biocoenosis (162 and 142 species), high monthly richness (91 \pm 13 and $80 \pm 10$ species) and by higher similarities (51.1-82.0 and 51.8-78.3\%) and peak richness during winter and autumn over two years of study. Zooplankton $(267 \pm 41 \mathrm{n} / \mathrm{l})$ formed a significant quantitative component $(56.0 \pm 6.3 \%)$ of net plankton and showed annual peak abundance during winter. Rotifera > Cladocera are dominant quantitative groups while Copepoda $>$ Rhizopoda are sub-dominant groups. We observed significant annual and monthly variations of zooplankton richness and abundance. This study showed limited influence of individual abiotic factors on zooplankton, with richness showing a significant inverse correlation with water hardness and chloride, and abundance inversely correlated with nitrate. Multiple regressions indicated higher cumulative effects of 15 abiotic factors on richness and abundance. Our results exhibited no definite periodicity of richness and abundance of zooplankton and their constituent groups during two annual cycles. Zooplankton is characterized by highest species diversity $(4.172 \pm 0.237)$, higher evenness and lower dominance.

Keywords: Abundance, community similarities, diversity indices, ecology, Ramsar site, richness.

\section{INTRODUCTION}

Zooplankton are integral components of aquatic food webs and contribute significantly to aquatic productivity in freshwater ecosystems. They have been studied from various inland aquatic environs of India, but a review of the limnological literature indicates limited information on their composition, ecology and role in aquatic productivity in the floodplain lakes in particular (Sharma \& Sharma 2008). The related contributions from the floodplain lakes of northeastern India (Sharma \& Hussain 2001; Sharma 2005; Sharma \& Sharma 2008) are as yet restricted to the beels of the Brahmaputra river basin of Assam.

The present study on synecology of zooplankton of Loktak Lake assumes special limnological significance in view of a lack of investigations in the floodplain lakes (pats) of Manipur. The observations are made on temporal variations in richness, community similarities, abundance, species diversity, dominance and evenness of zooplankton of this important floodplain lake, a Ramsar site of India. In addition, the influence of abiotic parameters on richness and abundance of zooplankton are analyzed.

\section{MATERIALS AND METHODS}

This study is a part of a limnological survey undertaken (November

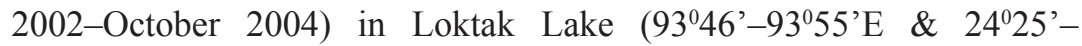


$\left.24^{\circ} 42^{\prime} \mathrm{N}\right)$ located in Bishnupur/Imphal districts of Manipur of India. Various common aquatic plants of this Ramsar site included Eichhornia crassipes, Hydrilla verticellata, Euryale ferox, Vallisnaria spiralis, Utricularia flexuosa, Trapa natans, Lemna trisula, Pistia striates, Salvinia sp. Nymphaea spp., Nymphoides spp., Nelumbo mucifera, Potamageton spp. and Azolla pinnata.

The observations were undertaken at one sampling site at Sendra $\left(93^{\circ} 47^{\prime} 45.61{ }^{\prime \prime} \mathrm{E} \& 24^{0} 30^{\prime} 56.75^{\prime} \mathrm{N}\right)$. Water samples were collected at regular monthly intervals and were analyzed for various abiotic factors following APHA (1992); water temperature, specific conductivity, $\mathrm{pH}$ and dissolved oxygen were recorded by the field probes. Qualitative (by towing) and quantitative plankton samples (by filtering 251 water each) were collected monthly by nylobolt

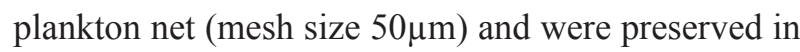
$5 \%$ formalin. The former were screened for various species and quantitative samples were analyzed for their abundance. Zooplankton species were identified following the works of Koste (1978), Michael \& Sharma (1988), Sharma (1998) and Sharma \& Sharma (1999a, 1990b, 2000, 2008). Community similarities (Sorensen's index), species diversity(Shannon's index), dominance (Berger-Parker's index) and evenness (Pileou's index) were calculated following Ludwig \&
Reynolds (1988) and Magurran (1988). Significance of temporal variations of biotic parameters was ascertained by ANOVA (two-way). The hierarchical cluster analysis, based on zooplankton community similarities, was done using SPSS (version 11.0). Ecological correlations between abiotic and biotic parameters were determined by simple correlation coefficients ( $\mathrm{r}$ ); their $\mathrm{P}$ values were calculated vide http://faculty.vassar.edu/lowry/tabs.html. and significance was ascertained after use of Bonferroni correction $(p<0.0033)$. Multiple regression $\left(R^{2}\right)$ was used to ascertain cumulative effect of 15 abiotic factors i.e., water temperature $\left(\mathrm{X}_{1}\right)$, rainfall $\left(\mathrm{X}_{2}\right), \mathrm{pH}\left(\mathrm{X}_{3}\right)$, specific conductivity $\left(\mathrm{X}_{4}\right)$, dissolved oxygen $\left(\mathrm{X}_{5}\right)$, free carbon dioxide $\left(\mathrm{X}_{6}\right)$, alkalinity $\left(\mathrm{X}_{7}\right)$, hardness $\left(\mathrm{X}_{8}\right)$, phosphate $\left(\mathrm{X}_{9}\right)$, nitrate $\left(\mathrm{X}_{10}\right)$, sulphate $\left(\mathrm{X}_{11}\right)$, silicate $\left(\mathrm{X}_{12}\right)$, chloride $\left(\mathrm{X}_{13}\right)$, dissolved organic matter $\left(\mathrm{X}_{14}\right)$ and total dissolved solids $\left(\mathrm{X}_{15}\right)$ on biotic factors.

\section{RESULTS AND DISCUSSION}

\section{Abiotic parameters}

Mean water temperature affirms sub-tropical range of Loktak Lake. Slightly acidic and soft waters of this Ramsar site are characterized by low specific conductivity (Table 1) depicting low ionic

Table 1. Abiotic factors of Loktak Lake

\begin{tabular}{|ll|c|c|c|}
\hline & & $\mathbf{2 0 0 2 - 0 3}$ & $\mathbf{2 0 0 3 - 0 4}$ & Study period \\
\hline Parameters & & Mean \pm SD & Mean \pm SD & Mean \pm SD \\
\hline Water Temperature & ${ }^{\circ} \mathrm{C}$ & $21.4 \pm 4.0$ & $22.2 \pm 4.1$ & $21.8 \pm 4.2$ \\
\hline Rainfall & $\mathrm{mm}$ & $112.1 \pm 116.8$ & $164.4 \pm 183.7$ & $138.2 \pm 154.8$ \\
\hline $\mathrm{pH}$ & & $6.38 \pm 0.23$ & $6.25 \pm 0.39$ & $6.31 \pm 0.32$ \\
\hline Specific Conductivity & $\mathrm{MS} / \mathrm{cm}$ & $98.9 \pm 19.7$ & $87.9 \pm 11.1$ & $93.3 \pm 17.1$ \\
\hline Dissolved oxygen & $\mathrm{mg} / \mathrm{l}$ & $6.2 \pm 1.1$ & $5.3 \pm 0.7$ & $5.7 \pm 1.1$ \\
\hline Free Carbon dioxide & $\mathrm{mg} / \mathrm{l}$ & $9.5 \pm 2.1$ & $8.9 \pm 2.0$ & $9.2 \pm 2.0$ \\
\hline Alkalinity & $\mathrm{mg} / \mathrm{l}$ & $16.0 \pm 4.4$ & $22.1 \pm 8.1$ & $19.1 \pm 7.1$ \\
\hline Hardness & $\mathrm{mg} / \mathrm{l}$ & $38.1 \pm 8.2$ & $38.4 \pm 7.2$ & $38.3 \pm 7.8$ \\
\hline Phosphate & $\mathrm{mg} / \mathrm{l}$ & $0.23 \pm 0.12$ & $0.21 \pm 0.04$ & $0.22 \pm 0.10$ \\
\hline Nitrate & $\mathrm{mg} / \mathrm{l}$ & $0.34 \pm 0.04$ & $0.30 \pm 0.03$ & $0.32 \pm 0.04$ \\
\hline Sulphate & $\mathrm{mg} / \mathrm{l}$ & $0.86 \pm 0.12$ & $0.87 \pm 0.12$ & $0.86 \pm 0.12$ \\
\hline Silica & $\mathrm{mg} / \mathrm{l}$ & $10.4 \pm 1.2$ & $9.7 \pm 1.6$ & $10.1 \pm 1.4$ \\
\hline Chloride & $\mathrm{mg} / \mathrm{l}$ & $14.9 \pm 3.1$ & $16.6 \pm 2.7$ & $15.8 \pm 3.0$ \\
\hline Dissolved organic $\mathrm{matter}$ & $\mathrm{mg} / \mathrm{l}$ & $1.38 \pm 0.40$ & $1.29 \pm 0.39$ & $1.34 \pm 0.39$ \\
\hline Total dissolved solids & $\mathrm{mg} / \mathrm{l}$ & $0.46 \pm 0.22$ & $0.43 \pm 0.17$ & $0.44 \pm 0.19$ \\
\hline
\end{tabular}


concentrations. Our results also indicate moderate dissolved oxygen, low free $\mathrm{CO}_{2}$, low concentrations of micro-nutrients and other abiotic factors.

\section{Zooplankton richness and community similarities}

Among 189 species of Zooplankton documented from Loktak Lake (Sharma unpublished), 169 species observed at the sampled site reflect speciose and diverse nature of their biocoenosis. Zooplankton comprise dominant qualitative component of net plankton (237 species) and significantly influence temporal variations of the latter $(r=0.960, p<0.0001)$. Overall zooplankton richness is the highest known till date from any floodplain lake or any individual aquatic ecosystem of India and, hence, reflects greater environmental heterogeneity of this Ramsar site. The richness is, however, notably higher than an unpublished report of 55 species (including undetermined and doubtful species) from this lake (Singh 1991). Besides, it is distinctly higher than the records from other Indian floodplain lakes i.e., 51 species (Khan 1987) and 26 species (Yousuf et al. 1986) from Kashmir; 19 species (Baruah et al. 1993) and 31 species (Sanjer \& Sharma 1995) from Bihar; 49 species (Sharma \& Hussain 2001) from Assam, and 71 species (Khan 2003) from West Bengal. Qualitative dominance of zooplankton in net plankton communities of Loktak Lake concurs with the findings of Sharma \& Sharma (2008) but differs from higher phytoplankton richness observed by Baruah et al. (1993), Sinha et al. (1994) and Sharma \& Hussain (2001). In general, zooplankton biocoenosis exhibits typical 'tropical character' and greater richness of cosmopolitan species while cosmotropical and pantropical species are well represented.

Monthly zooplankton richness varies between 69$121(85 \pm 13)$ species during the study period (Table 2); it registers significant annual $\left(\mathrm{F}_{1,23 .}=26.712, \mathrm{p}<0.005\right)$ and monthly variations $\left(\mathrm{F}_{11,23 .}=10.752, \mathrm{p}<0.005\right)$. Richness ranges between $91 \pm 13$ and $85 \pm 13$ species during two years and shows annual maxima during winter (December 2002) and autumn (November 2003) respectively. Qualitative diversity is higher

Table 2. Temporal variations of Zooplankton of Loktak Lake

\begin{tabular}{|c|c|c|c|c|c|c|}
\hline & \multicolumn{2}{|c|}{ 2002-03 } & \multicolumn{2}{|c|}{ 2003-2004 } & \multicolumn{2}{|c|}{ Study period } \\
\hline \multicolumn{7}{|l|}{ Qualitative } \\
\hline $\begin{array}{l}\text { Net Plankton } \\
\text { Monthly richness }\end{array}$ & \multicolumn{2}{|c|}{237 species } & \multicolumn{2}{|c|}{213 species } & \multicolumn{2}{|c|}{237 species } \\
\hline \multirow{2}{*}{$\begin{array}{l}\text { Zooplankton } \\
\text { Monthly richness }\end{array}$} & \multicolumn{2}{|c|}{169 species } & \multicolumn{2}{|c|}{142 species } & \multicolumn{2}{|c|}{169 species } \\
\hline & $76-121$ & $91 \pm 13$ & $69-98$ & $80 \pm 10$ & 69-121 & $85 \pm 13$ \\
\hline Rotifera & $47-79$ & $57 \pm 10$ & $41-60$ & $48 \pm 6$ & $41-79$ & $53 \pm 9$ \\
\hline Cladocera & $19-31$ & $23 \pm 5$ & $17-30$ & $22 \pm 4$ & $17-31$ & $22 \pm 4$ \\
\hline Rhizopoda & $5-9$ & $7 \pm 1$ & $4-8$ & $6 \pm 1$ & $4-9$ & $6 \pm 1$ \\
\hline \multicolumn{7}{|l|}{ Quantitative } \\
\hline Zooplankton (n/l) & 204-319 & $246 \pm 35$ & $256-314$ & $287 \pm 34$ & 204-319 & $267 \pm 41$ \\
\hline$\%$ composition & $39.4-62.0$ & $54.9 \pm 6.6$ & $45.2-65.2$ & $57.1 \pm 5.8$ & $39.4-65.2$ & $56.0 \pm 6.3$ \\
\hline Diversity & \multicolumn{2}{|c|}{$\begin{array}{c}3.750-4.639 \\
4.186 \pm .0 .278\end{array}$} & \multicolumn{2}{|c|}{$\begin{array}{c}3.912-4.519 \\
4.158 \pm 0.185\end{array}$} & \multicolumn{2}{|c|}{$\begin{array}{c}3.750-4.639 \\
4.172 \pm 0.237\end{array}$} \\
\hline Dominance & \multicolumn{2}{|c|}{$\begin{array}{c}0.044-0.170 \\
0.087 \pm 0.019\end{array}$} & \multicolumn{2}{|c|}{$\begin{array}{c}0.044-0.101 \\
0.071 \pm 0.019\end{array}$} & \multicolumn{2}{|c|}{$\begin{array}{c}0.044-0.170 \\
0.079 \pm 0.033\end{array}$} \\
\hline Evenness & \multicolumn{2}{|c|}{$\begin{array}{c}0.853-0.992 \\
0.929 \pm 0.040\end{array}$} & \multicolumn{2}{|c|}{$\begin{array}{c}0.903-0.988 \\
0.950 \pm 0.024\end{array}$} & \multicolumn{2}{|c|}{$\begin{array}{c}0.853-0.992 \\
0.939 \pm 0.035\end{array}$} \\
\hline Rotifera & $84-157$ & $113 \pm 23$ & $115-188$ & $136 \pm 22$ & 84-188 & $125 \pm 25$ \\
\hline Cladocera $\quad(n / l)$ & $42-108$ & $66 \pm 20$ & 69-103 & $79 \pm 9$ & $42-108$ & $72 \pm 18$ \\
\hline Copepoda $\quad(n / l)$ & $19-87$ & $48 \pm 21$ & $26-64$ & $44 \pm 11$ & $19-87$ & $45 \pm 16$ \\
\hline Rhizopoda $\quad(n / l)$ & $11-22$ & $18 \pm 4$ & $15-36$ & $27 \pm 6$ & $11-36$ & $22 \pm 7$ \\
\hline Ostracoda $\quad(n / l)$ & $0-3$ & $1 \pm 1$ & $0-2$ & $1 \pm 1$ & $0-3$ & $1 \pm 1$ \\
\hline Gastrotricha $\quad(n / l)$ & \multicolumn{2}{|c|}{$0-1$} & \multicolumn{2}{|c|}{$0-2$} & \multicolumn{2}{|c|}{$0-1$} \\
\hline Conchostraca (n/l) & \multicolumn{2}{|c|}{$0-1$} & \multicolumn{2}{|c|}{$0-1$} & \multicolumn{2}{|c|}{$0-1$} \\
\hline
\end{tabular}


throughout first year except during July. In general, this study records (Figs. $1 \&$ 2) relatively lower number of species from February-July during first year while this trend is noticed from January-August in the succeeding year. Individual abiotic factors exert limited influence on zooplankton richness; it registers only significant negative correlations with hardness $(\mathrm{r}=-0.650, \mathrm{p}=0.0011)$ and chloride $(\mathrm{r}=-0.723, \mathrm{p}$ $=0.0002)$. On the other hand, multiple regression (Table 3) indicates higher cumulative effect of 15 abiotic factors on richness $\left(\mathrm{R}^{2}=0.863\right)$.

The collections examined from the selected study site indicate Rotifera (104 species) $>$ Cladocera (41 species) $>$ Rhizopoda (17 species). The faunal diversity of Rotifera and Cladocera of Loktak Lake is explained separately by Sharma (2009a), and Sharma \& Sharma (2009a) respectively. Monthly richness (Figs. 1 \& 2) of Rotifera ranges between 41-79 (53 \pm 9$)$ species during the study period with annual ranges of $57 \pm 10$ and $48 \pm 6$ species respectively (Table 2). Cladocera monthly richness ranges between 17-31 (22 \pm 4$)$ species and annual mean richness between $23 \pm 5$ and $22 \pm 4$ species respectively while Rhizopoda record lower mean annual richness ( $7 \pm 1$ and $6 \pm 1$ species). The qualitative dominance of the rotifers concurs with the reports of Sharma (2000a, 2000b, 2005), Sharma \& Sharma $(2001,2005,2008)$ and Khan $(2002,2003)$. Further, zooplankton or their constituent groups follow no definite pattern of periodicity of richness in this Ramsar site.

Zooplankton communities indicate (Tables 4 \& 5) only marginally different i.e., 51.1-82.0 \% and 51.8-78.2\% annual similarity ranges (vide Sorenson's index). Peak similarities are observed between December-October and February-September while minima are noticed between April-August and

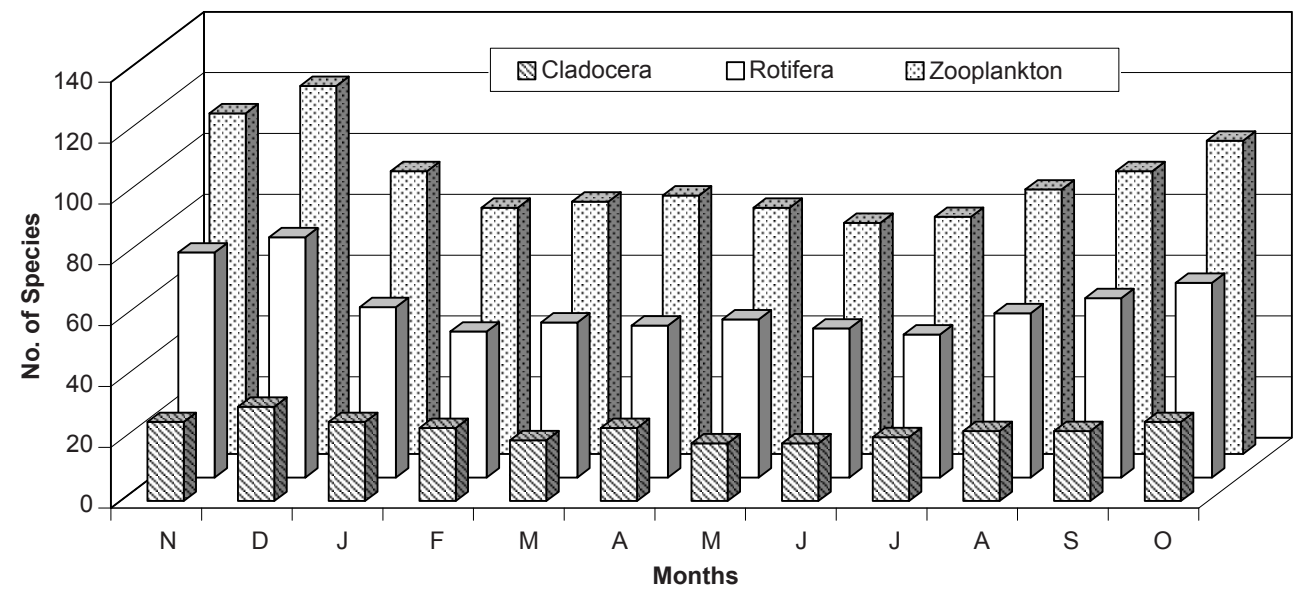

Figure 1. Monthly variations in richness of zooplankton, Rotifera and Cladocera (2002-03)

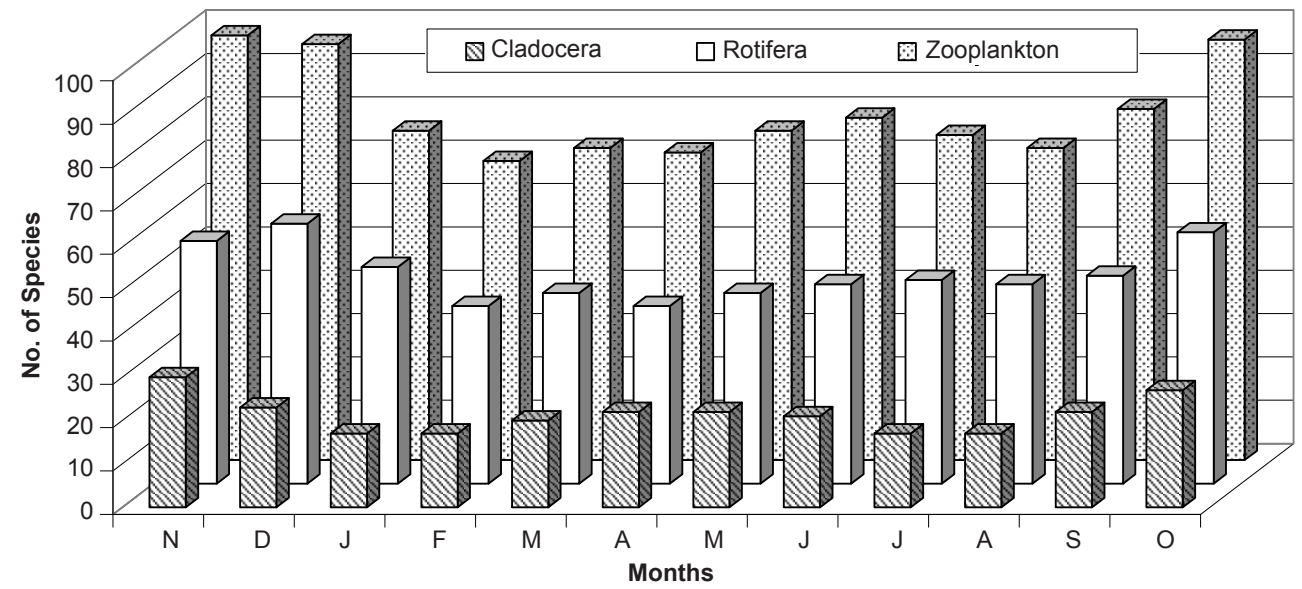

Figure 2. Monthly variations in richness of zooplankton, Rotifera and Cladocera (2003-04) 


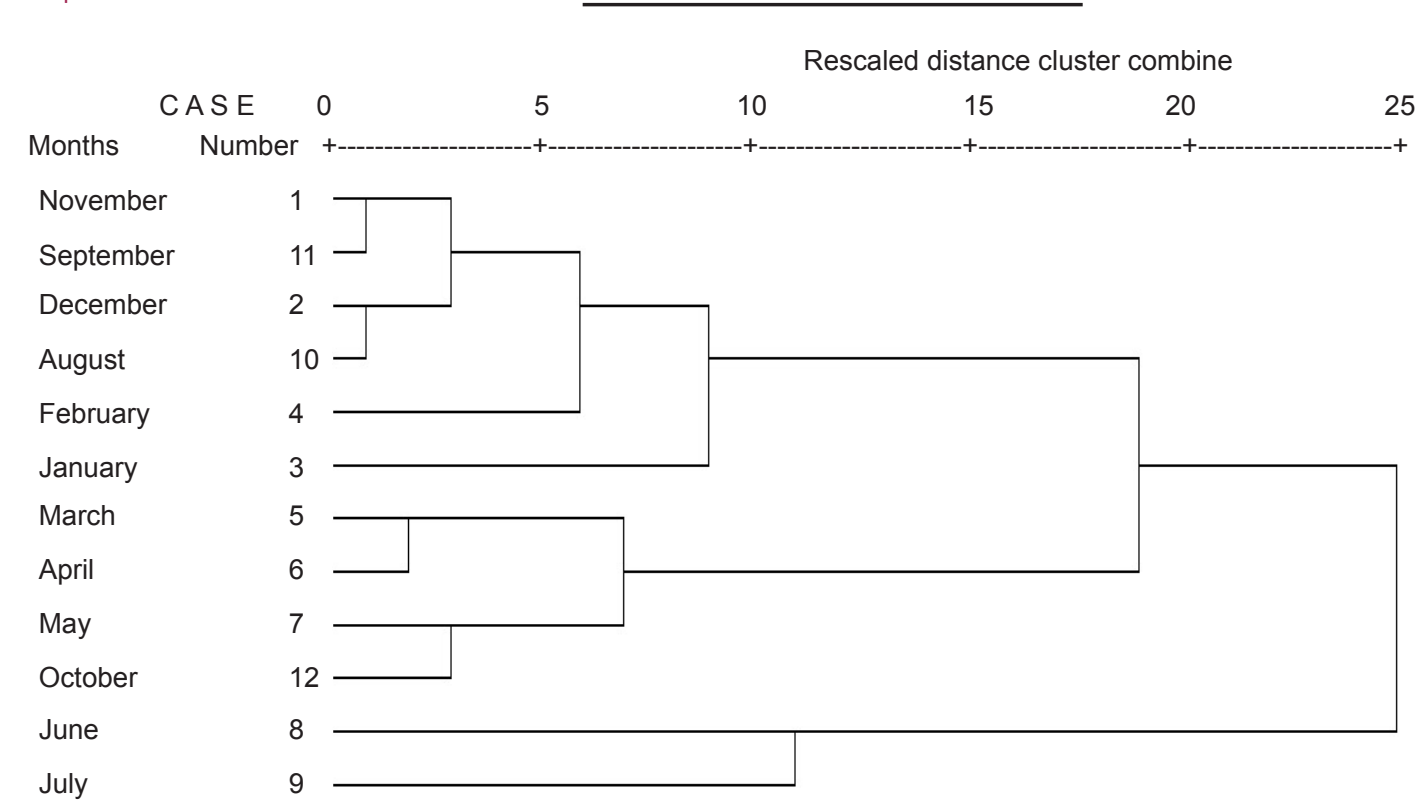

Figure 3. Hierarchical cluster analysis of zooplankton (2002-03)

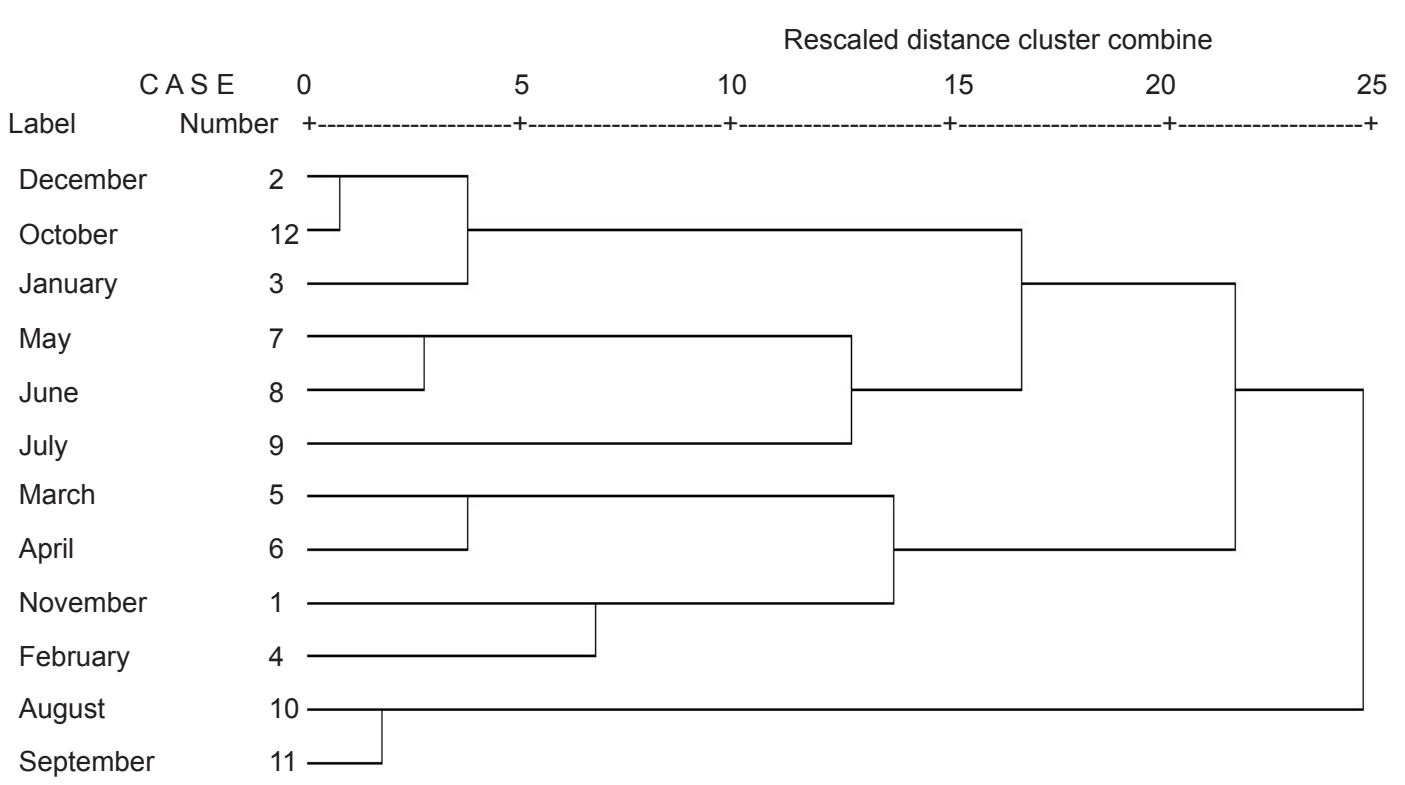

Figure 4. Hierarchical cluster analysis of zooplankton (2003-04)

May-July communities during two years respectively. Similarity matrices exhibit broadly concurrent maximum instances $(50.0 \%$ and $48.3 \%)$ of $60-70 \%$ similarity in both years but show different patterns of cluster analysis (Figs. $3 \& 4$ ). The hierarchical cluster analysis shows (Fig. 3) closeness in zooplankton composition between December-October, May-June, March-April and August-September; the last group, however, shows distinct divergence from rest of the monthly collections during 2002-03. In the following year (Fig. 4), greater zooplankton similarity is noticed between November-September, December-August, March-April and May-October while June-July communities indicate diverse composition.

\section{Zooplankton abundance}

Abundance of zooplankton(Table 2) ranges between 204-319 (267 \pm 41$) \mathrm{n} / \mathrm{l}$ and indicates significant annual $\left(\mathrm{F}_{1,23}=32.096, \mathrm{p}<0.005\right)$ and monthly variations $\left(\mathrm{F}_{11,23}=7.132, \mathrm{p}<0.005\right)$. The density is apparently higher than the reports of Yadava et al. (1987), Baruah et al. (1993) and Sharma \& Hussain (2001) and it is, 


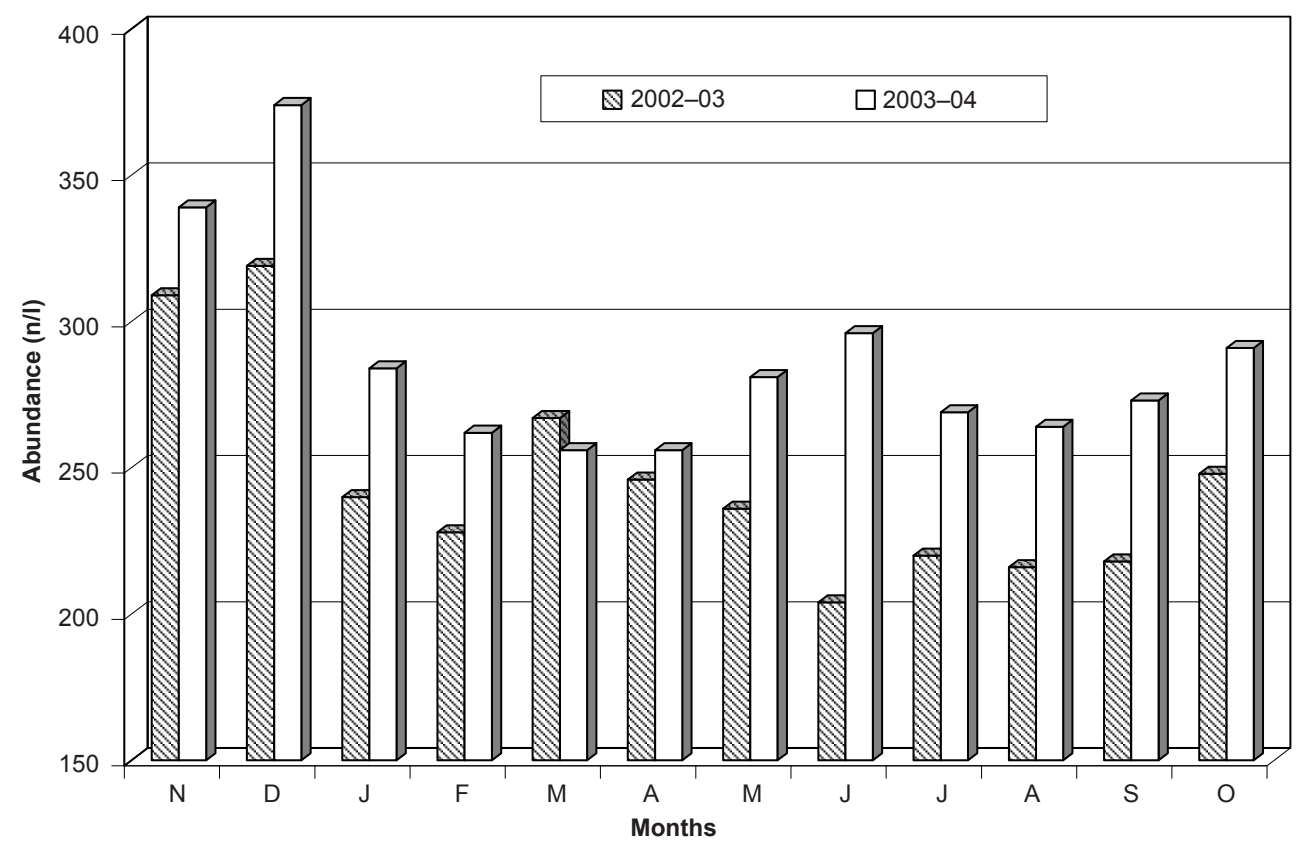

Figure 5. Monthly variations in abundance of zooplankton

Table 3. Multiple regressions between abiotic parameters and zooplankton

\begin{tabular}{|c|}
\hline Zooplankton richness \\
\hline$Y=80.424-0.218\left(X_{1}\right)+0.004\left(X_{2}\right)+22.829\left(X_{3}\right)+0.422\left(X_{4}\right)-3.756\left(X_{5}\right)+3.116\left(X_{6}\right)-1.191\left(X_{7}\right)-0.717\left(X_{8}\right)+48.906\left(X_{9}\right)-106.975\left(X_{10}\right)-$ \\
$67.274\left(X_{11}\right)-3.785\left(X_{12}\right)-0.613\left(X_{13}\right)-0.108\left(X_{14}\right)-3.252\left(X_{15}\right) R^{2}=0.863$ \\
\hline Zooplankton abundance \\
\hline$Y=420.371+0.823\left(X_{1}\right)+0.065\left(X_{2}\right)-0.126\left(X_{3}\right)+0.790\left(X_{4}\right)-16.838\left(X_{5}\right)+14.226\left(X_{6}\right)-0.020\left(X_{7}\right)-2.208\left(X_{8}\right)+36.539\left(X_{9}\right)-463.853\left(X_{10}\right)-$ \\
$25.335\left(X_{11}\right)-9.550\left(X_{12}\right)+3.727\left(X_{13}\right)+49.283\left(X_{14}\right)-149.027\left(X_{15}\right) R^{2}=0.851$
\end{tabular}

water temperature $\left(X_{1}\right)$, rainfall $\left(X_{2}\right), \mathrm{pH}\left(X_{3}\right)$, specific conductivity $\left(X_{4}\right)$, dissolved oxygen $\left(X_{5}\right)$, free carbon dioxide $\left(X_{6}\right)$, alkalinity $\left(X_{7}\right)$, hardness $\left(X_{8}\right)$, phosphate $\left(X_{9}\right)$, nitrate $\left(X_{10}\right)$, sulphate $\left(X_{11}\right)$, silicate $\left(X_{12}\right)$, chloride $\left(X_{13}\right)$, dissolved organic matter $\left(X_{14}\right)$ and total dissolved solids $\left(X_{15}\right)$

however, lower than the results of Khan (1987), Sanjer \& Sharma (1995) and Khan (2002). The abundance shows (Fig. 5) broadly trimodal annual patterns with peaks during winter (December 2002 and December 2003). The stated patterns differ from bimodal periodicity noticed by Yadava et al. (1987) and Sanjer \& Sharma (1995) while these concur with the findings of Sharma \& Hussain (2001). Abundance is noticed to be relatively higher $(287 \pm 34 \mathrm{n} / \mathrm{l})$ throughout the second year except only during March.

Zooplanktoncomprisemain quantitative component (39.4 - 65.2, 56.0 \pm 6.3$) \%$ of net plankton $(480 \pm 74 \mathrm{n} / \mathrm{l})$ and contribute significantly to their temporal variations $(\mathrm{r}=0.652, \mathrm{p}=0.0012)$. The quantitative dominance of zooplankton of Loktak Lake, in turn, concurs with the results of Sharma \& Hussain (2001). This salient feature is in contrast to higher phytoplankton abundance reported from the floodplain lakes and wetlands from different parts of India i.e., Kashmir (Kaul \& Pandit 1982), Bihar (Baruah et al. 1993; Sanjer \& Sharma 1995), West Bengal (Sugunan 1989) and Assam (Yadava et al. 1987). Abundance records only significant inverse correlation with nitrate $(\mathrm{r}=$ $-0.697, p=0.0003$ ) showing very limited influence of individual abiotic while multiple regression indicates (Table 3) higher cumulative effect of 15 abiotic factors on zooplankton abundance $\left(\mathrm{R}^{2}=0.851\right)$.

Amongst different groups (Figs. 6 \& 7), Rotifera form $(46.6 \pm 4.1 \%))$ an important quantitative component of zooplankton and contribute significantly $(\mathrm{r}=0.974)$ to their abundance; Cladocera $(27.1 \pm 5.0$ $\%)$ and Copepoda (17.4 $\pm 7.2 \%)$ also contribute to their abundance while Rhizopoda (Table 2) comprise between $8.3 \pm 2.0 \%$. Other groups of zooplankton, namely, Ostracoda, Gastrotricha and Conchostraca indicate very poor abundance (Table 2). The 


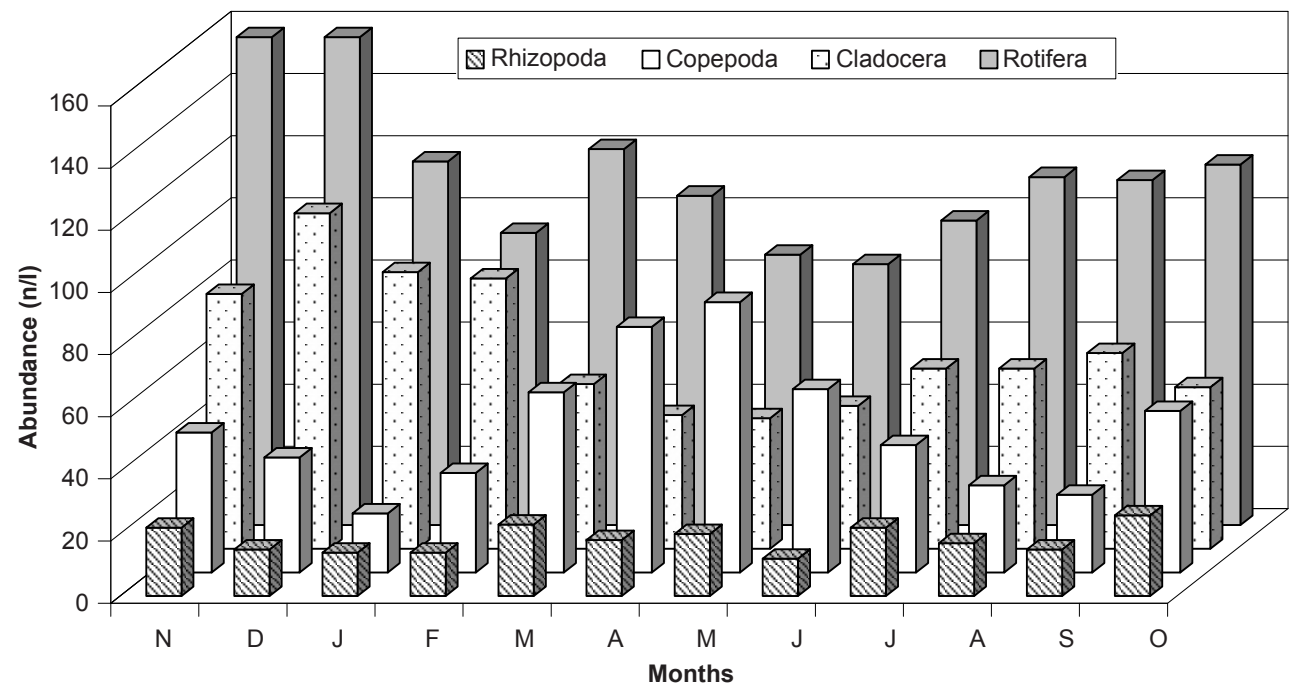

Figure 6. Monthly variations in abundance of different groups of zooplankton (2002-03)

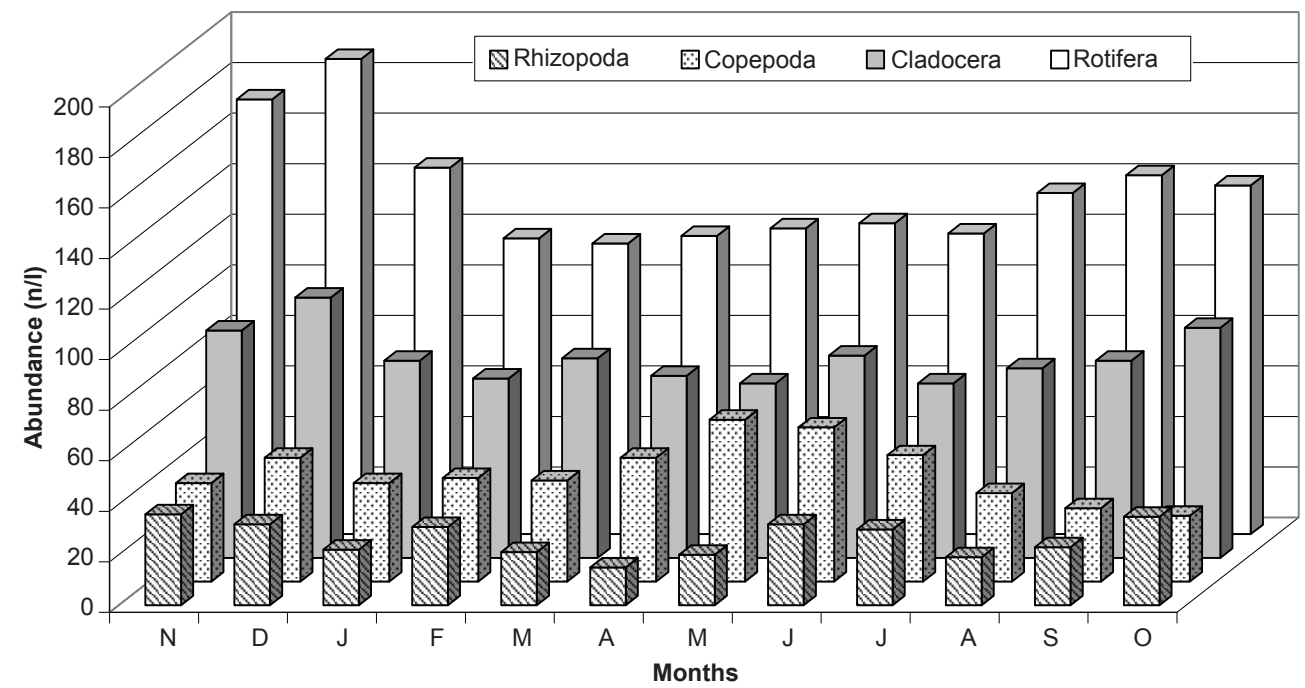

Figure 7. Monthly variations in abundance of different groups of zooplankton (2003-04)

synecology of Rotifera and micro-crustaceans are dealt with separately by Sharma (2009b) and Sharma \& Sharma (2009b) respectively. In general, zooplankton and their constituent groups follow no definite pattern of quantitative periodicity in Loktak Lake.

\section{Species diversity, evenness and dominance}

Zooplankton show the highest species diversity (3.750-4.639, 4.172 \pm 0.237$)$ so far known from any floodplain lake or aquatic ecosystem of northeastern India and elsewhere from this country (Sharma unpublished). This salient feature affirms higher environmental heterogeneity of Loktak Lake. It registers significant monthly $\left(\mathrm{F}_{11,23}=3.762, \mathrm{p}<0.01\right)$, shows (Table 2$)$ relatively higher values $(4.186 \pm 0.278)$ during the second year and exhibits broadly bimodal but different annual patterns (Fig. 8) with peaks during winter (December 2002) and post-monsoon (October 2004) and minima during summer (May). In general, higher species diversity $(<4.0)$ is observed during November-February, July and September-October during both years and again during May and June $\left(2^{\text {nd }}\right.$ year) and August ( $1^{\text {st }}$ year). The notable feature of higher species diversity with relatively lower densities of majority of species noticed in this study may be ascribed to fine niche portioning amongst zooplankton species in combination with high micro- and macroscale habitat heterogeneity as hypothesized by Segers 


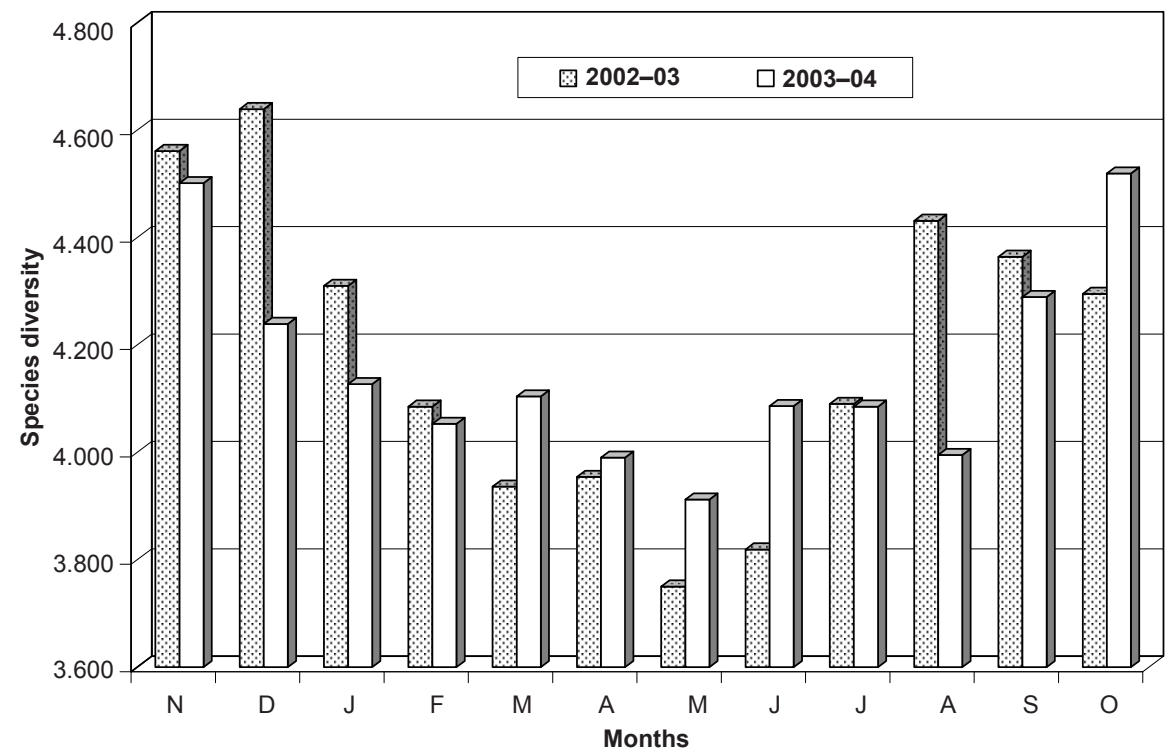

Figure 8. Monthly variations in species diversity of zooplankton

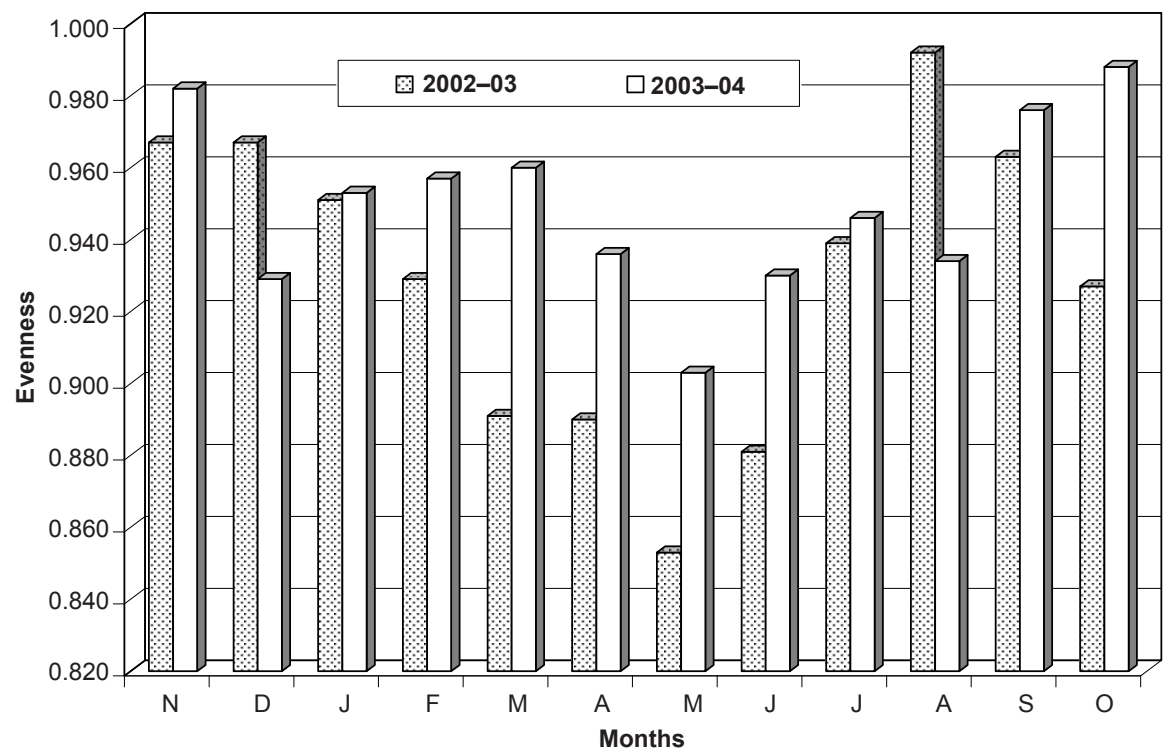

Figure 9. Monthly variations in evenness of zooplankton

(2008).

This study depicts (Table 2) higher evenness $(0.813-0.992, \quad 0.939 \pm 0.032)$ of zooplankton; this feature affirms equitable abundance of various species and concurs with the results of Sharma \& Hussain (2001) and Sharma \& Sharma (2008). It follows (Fig. 9) bimodal and multimodal annual patterns with peaks during August and October during the two years respectively while minima are noticed during summer (May). Zooplankton show (Table 2) lower dominance $(0.044-0.170,0.079 \pm 0.033)$ indicating lack of quantitative importance of individual species. This feature again concurs with the results of Sharma \& Hussain (2001) and Sharma \& Sharma (2008). It registers only significant monthly variations $\left(\mathrm{F}_{11,23}=\right.$ 3.896, $\mathrm{p}<0.01$ ), and follows (Fig. 10) different annual patterns with maxima during April and May during two years respectively.

To sum up, zooplankton form important qualitative and quantitative components of net plankton, exhibit highly speciose character with richest diversity and quantitative dominance of Rotifera > Cladocera, 


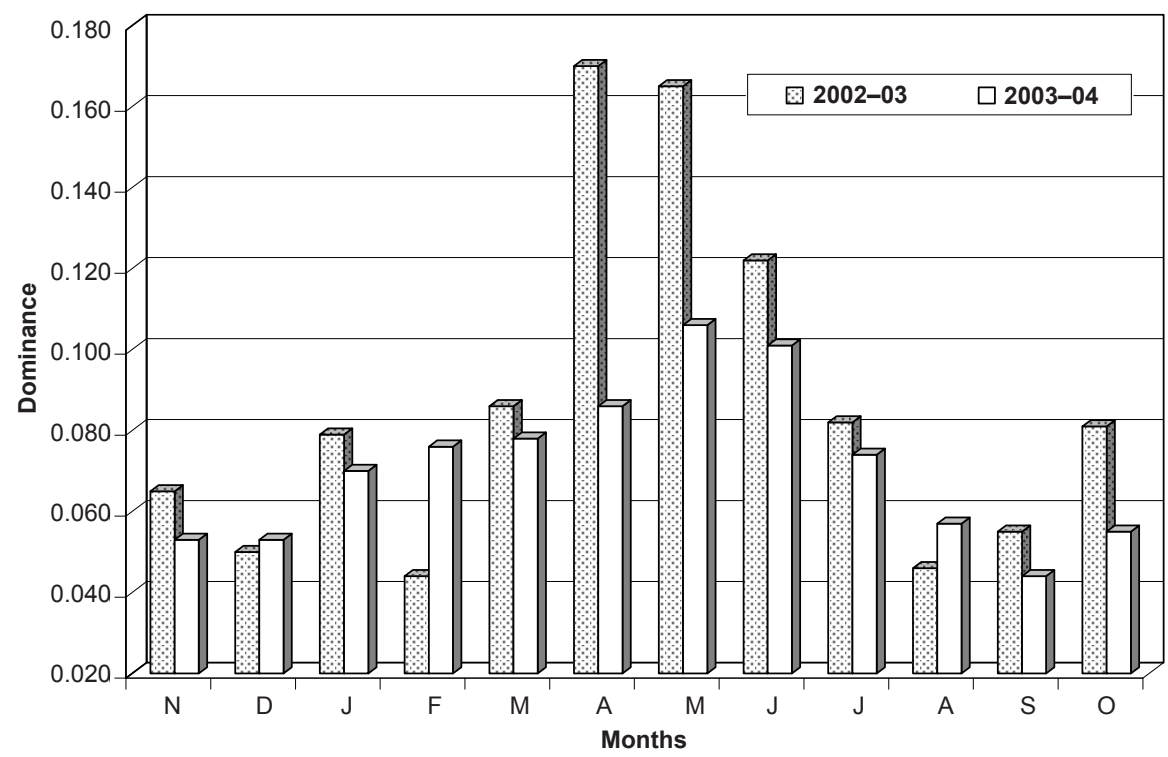

Figure 10. Monthly variations in dominance of zooplankton

Table 4. Percentage similarities between Zooplankton communities (2002-03)

\begin{tabular}{|c|c|c|c|c|c|c|c|c|c|c|c|c|}
\hline & Nov & Dec & Jan & Feb & March & April & May & June & July & Aug & Sept & Oct \\
\hline Nov & - & 76.7 & 70.2 & 61.8 & 62.1 & 64.3 & 75.4 & 67.9 & 63.2 & 75.0 & 76.7 & 71.2 \\
\hline Dec & & - & 75.4 & 70.6 & 59.3 & 61.5 & 66.7 & 65.4 & 71.7 & 76.9 & 75.0 & 72.7 \\
\hline Jan & & & - & 70.8 & 58.8 & 53.1 & 55.6 & 69.4 & 72.0 & 73.5 & 75.5 & 65.4 \\
\hline Feb & & & & - & 77.5 & 63.8 & 65.4 & 63.8 & 58.3 & 76.6 & 78.3 & 72.0 \\
\hline Mar & & & & & - & 76.0 & 72.7 & 56.0 & 58.8 & 64.0 & 70.4 & 71.7 \\
\hline Apr & & & & & & - & 75.5 & 54.2 & 57.1 & 52.5 & 65.4 & 74.5 \\
\hline May & & & & & & & - & 67.9 & 51.8 & 67.9 & 73.7 & 75.0 \\
\hline Jun & & & & & & & & - & 69.4 & 62.5 & 61.5 & 70.6 \\
\hline Jul & & & & & & & & & - & 65.3 & 56.6 & 57.7 \\
\hline Aug & & & & & & & & & & - & 76.9 & 70.6 \\
\hline Sep & & & & & & & & & & & - & 72.3 \\
\hline Oct & & & & & & & & & & & & - \\
\hline
\end{tabular}

Table 5. Percentage similarities between Zooplankton communities (2003-04)

\begin{tabular}{|c|c|c|c|c|c|c|c|c|c|c|c|c|}
\hline & Nov & Dec & Jan & Feb & March & April & May & June & July & Aug & Sept & Oct \\
\hline Nov & - & 66.7 & 61.0 & 76.4 & 75.0 & 67.9 & 71.4 & 77.2 & 67.9 & 74.1 & 80.0 & 75.4 \\
\hline Dec & & - & 81.4 & 61.8 & 57.1 & 60.4 & 67.9 & 66.7 & 67.9 & 70.4 & 58.2 & 82.0 \\
\hline Jan & & & - & 70.4 & 65.5 & 65.4 & 61.8 & 60.7 & 69.1 & 67.9 & 55.6 & 73.7 \\
\hline Feb & & & & - & 70.6 & 70.8 & 58.8 & 69.2 & 64.0 & 65.3 & 64.0 & 67.9 \\
\hline Mar & & & & & - & 77.5 & 57.7 & 60.4 & 62.7 & 60.0 & 62.7 & 66.7 \\
\hline Apr & & & & & & - & 65.3 & 52.0 & 54.2 & 51.1 & 54.2 & 59.3 \\
\hline May & & & & & & & - & 79.2 & 62.7 & 52.0 & 54.9 & 66.7 \\
\hline Jun & & & & & & & & - & 73.1 & 54.9 & 61.5 & 75.9 \\
\hline Jul & & & & & & & & & - & 65.3 & 56.0 & 64.3 \\
\hline Aug & & & & & & & & & & - & 81.6 & 72.7 \\
\hline Sep & & & & & & & & & & & - & 64.3 \\
\hline Oct & & & & & & & & & & & & - \\
\hline
\end{tabular}


and indicate no definite periodicity of richness or abundance of zooplankton or their constituent groups. zooplankton are characterized by highest species diversity, higher evenness and lower dominance, and exhibit lower densities of majority of species. This study registers limited influence of individual abiotic factors but records higher cumulative influence of 15 abiotic factors on richness and abundance. The present observations limited to one sampling station, though provide useful information on composition, production and ecology of zooplankton yet may not reflect full view of heterogeneity of this interesting Ramsar site. Further studies in different parts (pats) of Loktak basin are, hence, desired and have been initiated.

\section{REFERENCES}

APHA (1992). Standard Methods for the Examination of Water and Wastewater (18 ${ }^{\text {th }}$ edition). American Public Health Association, Washington D.C.

Baruah, A., A.K. Sinha \& U.P. Sharma (1993). Plankton variability of a tropical wetland, Kawar (Begusarai), Bihar. Journal of Freshwater Biology 5: 27-32.

Kaul, V. \& A.K. Pandit (1982). Biotic factors and food chain structure in some typical wetlands of Kashmir. Pollution Research 1: 49-54.

Khan, M.A. (1987). Observations on zooplankton composition, abundance and periodicity in two flood plain lakes of the Kashmir Himalayan valley. Acta Hydrochemica Hydrobiologia 15: 167-174.

Khan, R. A. (2002). The ecology and faunal diversity of two floodplain Ox-bow lakes of south-eastern West Bengal. Records of the Zoological Survey of India, Occasional Paper No. 195: 1-57.

Khan, R.A. (2003). Faunal diversity of zooplankton in freshwater wetlands of southeastern West Bengal. Records of the Zoological Survey of India, Occasional Paper No. 204: 1-107.

Koste, W. (1978). ROTATORIA. Die Rädertiere Mitteleuropas, begründet von Max Voigt. Überordnung Monogononta. Gebrüder Borntraeger, Berlin, Stuttgart. I. Text (673 pp) U. II. Tafelbd. (T. 234).

Ludwig, J.A. \& J. F. Reynolds (1988). Statistical Ecology: A Primer on Methods and Computing. John Wiley \& Sons, New York, 337pp.

Magurran, A.E. (1988). Ecological Diversity and its Measurement. Croom Helm Limited, London, 179pp.

Michael,R.G.\& B.K.Sharma(1988). INDIANCLADOCERA. (Crustacea: Branchiopoda: Cladocera). Fauna of India and adjacent countries Series. Published by Zoological Survey of India, Calcutta, 262pp.

Sanjer, L.R. \& U.P. Sharma (1995). Community structure of plankton in Kawar lake wetland, Begusarai, Bihar: II Zooplankton. Journal of Freshwater Biology 7: 165-167.

Segers, H. (2008). Global diversity of rotifers (Rotifera) in freshwater. Hydrobiologia 595: 49-59.

Sharma, B.K. (1998). Freshwater Rotifers (Rotifera: Eurotatoria). In: Fauna of West Bengal. State Fauna Series 3(11): 341-461. Zoological Survey of India, Calcutta.

Sharma, B.K. (2000a). Rotifers from some tropical floodplain lakes of Assam (N.E. India). Tropical Ecology 41(2): 175-181.

Sharma, B.K. (2000b). Synecology of Rotifers in a tropical floodplain lake of Upper Assam (N. E. India). The Indian Journal of Animal Sciences 70: 880-885.

Sharma, B.K. (2005). Rotifer communities of floodplain lakes of the Brahmaputra basin of lower Assam (N.E. India): biodiversity, distribution and ecology. Hydrobiologia 533: 209-221.

Sharma, B. K. (2009a). Diversity of Rotifers (Rotifera: Eurotatoria) of Loktak lake, North-Eastern India. Tropical Ecology 50(2): 277-285.

Sharma, B.K. (2009b). Richness, abundance and ecology of Rotifera of Loktak Lake (a Ramsar site), Manipur, Northeastern India. Ecology, Environment \& Conservation 15(2): 299-306.

Sharma, B.K. \& M. Hussain (2001). Abundance and ecology of Zooplankton in a tropical floodplain lake, Assam (N.E. India). Ecology, Environment \& Conservation 7(4): $397-$ 403.

Sharma, B. K. \& S. Sharma (1999a). Freshwater Rotifers (Rotifera: Eurotatoria). In: State Fauna Series: Fauna of Meghalaya. 4(9): 11-161. Zoological Survey of India, Calcutta.

Sharma, B. K. \& S. Sharma (1999b). Freshwater Cladocerans (Crustacea: Branchiopoda: Cladocera). In: State Fauna Series: Fauna of Meghalaya 4(9): 469 -550. Zoological Survey of India, Calcutta.

Sharma, B.K. \& S. Sharma (2000). Freshwater Rotifers (Rotifera: Eurotatoria). In: State Fauna Series: Fauna of Tripura 7(4): 163-224. Zoological Survey of India, Calcutta.

Sharma, B.K. \& S. Sharma (2001). Biodiversity of Rotifera in some tropical floodplain lakes of the Brahmaputra river basin, Assam (N.E. India). Hydrobiologia 446/447: 305313.

Sharma, B.K. \& S. Sharma (2005). Faunal diversity of Rotifers (Rotifera: Eurotatoria) of Deepor beel, Assam (N.E. India) - a Ramsar site. Journal of the Bombay Natural History Society 102(2): 169-175.

Sharma, B. K. \& S. Sharma (2009a). Faunal diversity of Cladocera (Crustacea: Branchiopoda) of Loktak Lake (a Ramsar site), Manipur (N.E. India). Journal of the Bombay Natural History Society 106(2): 156-161.

Sharma, B.K. \& S. Sharma (2009b). Diversity of microcrustacea (Crustacea: Branchiopoda) of Loktak lake, a Ramsar site, Manipur, India. Journal of Threatened Taxa 1(11): 541-548. 
Sharma, S. \& B.K. Sharma (2008). Zooplankton diversity in floodplain lakes of Assam. Records of the Zoological Survey of India, Occasional Paper No. 290: 1-307.

Singh, R.K.S. (1991). Study of nutrient enrichment in Loktak lake with reference to Biological indices. PhD Thesis. Manipur University, Manipur.

Sinha, A.K., A. Baruah, D.K. Singh \& U.P. Sharma (1994). Biodiversity and pollution status in relation to physicochemical factors of Kawar lake Begusarai), North Bihar. Journal of Freshwater Biology 6: 309-331.
Sugunan, V.V. (1989). Limnological features in beels: Biotic factors. Bulletin of the Central Inland Capture Fisheries Research Institute, Barrackpore 63: 128- 135.

Yadava, Y.S., R.K. Singh, M. Choudhury \& V. Kolekar (1987). Limnology and productivity in Dighali beel (Assam). Tropical Ecology 28: 137-146.

Yousuf, A.R., G.M. Shah \& M.Y. Qadri (1986). Some limnological aspects of Mirgund wetland. Geobios New Reports 5: 27-30. 